Volume 13 Number 2, April-June 2019: pp. 129-150. Copyright (c) 2019 FIAT JUSTISIA. Faculty of Law, Lampung University, Bandarlampung, Lampung, Indonesia. ISSN: 1978-5186 | e-ISSN: 2477-6238.Open Access: http://jurnal.fh.unila.ac.id/index.php/fiat

Fiat Justisia is licensed under a Creative Commons Attribution 4.0 International License, which permits unrestricted use, distribution, and reproduction in any medium, provided the original work is properly cited.

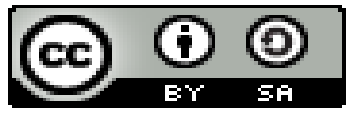

\title{
Regulate DPR's Committees: Making Indonesian Presidential System More Representative
}

\author{
Zulkarnain Ridlwan \\ Faculty of Law, University of Lampung, Indonesia \\ zulkarnain.ridlwan@fh.unila.ac.id \\ Zainal Arifin Mochtar \\ Faculty of Law, Universitas Gadjah Mada, Indonesia \\ zainalarifinmochtar@ugm.ac.id
}

\begin{abstract}
The evaluation of the DPR's oversight function always considered not to represent the will of critical supervision of the people in almost every DPR's performance satisfaction survey. The DPR Committees institutionally the main actor of supervision, but has not been effective. 11 DPR committees compared to 113 work partners suspected to be one of the causes. Committees formed by DPR and can be adjusted according to needs. Based on a comparative approach on regulations in the US Congress and the British Parliament, it is recommended to narrow the oversight work by increasing the number of DPR committees to balance a large number of partners. The division of supervision work into more committees makes the scope of work narrow so that supervision is more focused. Changes in the arrangement of the number of committees in Law 17/2014 and the DPR 2014 Rules of Conduct need to be done by stating the maximum number of five working partners for each committee. The creativity of the committee to form sub-committees following needs must also be confirmed in the 2014 DPR Rules of Conduct. Such regulation is expected to make the performance of checks and balances between the DPR and the Government better assessed by the public as a unitary presidential government system, namely a presidential system that better represents the will of the people's supervision.
\end{abstract}

Keywords: Committees, DPR/ Indonesian People's Representative Council, Oversight Function, Presidential System, Regulate. 
How to Cite: Zulkarnain Ridlwan, Zainal Arifin Mochtar, "Regulate DPR's Committees: Making Indonesian Presidential System More Representative", Fiat Justisia, 13 (2), (2019).

DOI: https://doi.org/10.25041/fiatjustisia.v13no2.1566

\section{A. Introduction}

The Expanse of states' history outlined that the portrait of power psychologically constant to be perverted. Because the tendency of rulers to expand their power and distort the use of power far greater than the ability to keep an eye on themselves. Therefore the authorities, with the power in his hand, need to be monitored. In the context of state, government as rulers should be supervised and should feel watched particularly by the parliament.

There is no agreement on the definition of parliamentary oversight, and so is the study of parliament; its understanding is still limited to theory ${ }^{1}$. There is little global analysis, which in principle done by Persson, et al., Treisman, Hope, Gerring and Thacker, and Lederman, et. al. ${ }^{2}$ Most of the research done on the scope of a particular country or region. ${ }^{3}$ These studies usually test the functions of the state parliament in general, and not focus solely or mainly on the oversight function. With more study of the oversight function in the United States, while fewer in other countries. ${ }^{4}$

Olson and Mezey also McCubbins and Schwartz refer the oversight associated with a series of parliamentary activities undertaken to evaluate the

\footnotetext{
${ }^{1}$ David M. Olson, "Legislatures and Administration in Oversight and Budgets: Constraints, Means and Executives." in Rick Stapenhurst, et.al. (Eds), Legislative Oversight and Budgeting: A World Perspective, Washington, D.C.: World Bank, (2008), pp. 323-331.

${ }^{2}$ Torsten Persson, et.al. (1997). "Separation of Powers and Political Accountability." Quarterly Journal of Economics Perspectives, 112, pp. 1163-1202; Daniel Treisman, (2000). "The Causes of Corruption: A Cross-National Study" Journal of Public Economics 76, 3:399-457; Kempe Ronald Hope, "Corruption and Development in Africa." in Kempe Ronald Hope Sr. and Bornwell C. Chikulu (Eds.), Corruption and Development in Africa: Lessons from Country Case-Studies. New York: St. Martin's Press, 2000), p. 17-39; John Gerring, and Strom Thacker, (2004). "Political Institutions and Corruption: The Role of Unitism and Parliamentarism." British Journal of Political Science, 34:295-330; Lederman, Daniel, et.al. (2005). "Accountability and Corruption: Political Institutions Do Matter." Economics and Politics, 17:1, p. 1-35.

${ }^{3}$ For example: Philip Norton and Nizam Ahmed. "Legislatures in Asia: Exploring Diversity." in Philip Norton and Nizam Ahmed (Eds.), Legislatures in Developmental Perspective, London: Frank Cass, (1999), pp. 1-12; David M. Olson, and Philip Norton, (Eds.). The New Parliaments of Central and Eastern Europe. London: Frank Cass, (1996).

${ }^{4}$ Frederick Stapenhurst, et.al,“Corruption and Legislatures”, Public Integrity, 16 (3), (2014), pp. 285-304.
} 
policy implementation ${ }^{5}$, also includes programs run by the government ${ }^{6}$. In the literature about parliamentary oversight, also known several terms represent oversight mechanism such as ex-ante, ex-post, sporadic actions (politely called 'fire-alarm' oversight), routine actions (so-called 'police-patrol' oversight) ${ }^{7}$

In the history of the Republic of Indonesia, DPR (Indonesian People's Representatives Council) and executive relations, particularly with the president, tend to be a mutually exclusive relationship. ${ }^{8}$ When the president is weak and has no effective power, DPR tends to function their authority more as a tool of political influence competition and bargain between parties. Not become effective power that is used to push for a settlement of the political problem. Conversely, if the executive, particularly the president, were strong, DPR tends only to be able to justify and legitimise policies taken by the executive.

That first condition occurred during the parliamentary period 1950 until July 1959. The second condition began after the President's decree on 5 of July 1959, passed during the whole time of the New Order. Which always visible, if DPR being weak, it became a justification tool of government policy. Conversely, if the Parliament being strong, it tempted to become a defender of his party. ${ }^{9}$

Configuration of political parties as government supporters in today's DPR similar to the dominance of government supporters in the New Order. The merger of three of five political parties (to the government) which had opposite each other in presidential elections, expressed concern at the fair will be at risk of forming oligarchy of power. It is needed to formulate the concept that political parties which are outside the government, although the numbers are small, can still bring optimal parliamentary oversight. So parliament with oversight functions can still be relied upon in overseeing the government by the people, not the dominance of the interests of ruling political parties. ${ }^{10}$

\footnotetext{
${ }^{5}$ David M. Olson, and Michael L. Mezey, ed. Legislatures in the Policy Process: The Dilemmas of Economic Policy, Cambridge: Cambridge University Press, (1991); Mathew McCubbins and Thomas Schwarz, "Congressional Oversight Overlooked: Police Patrols Versus Fire Alarms", American Journal of Political Science, 28 (1), (1984), pp.65-79.

${ }^{6}$ Allen Schick, "Congress and the Details of Administration." Public Administration Review, 36 (5), (1976). pp.16-528.

${ }^{7}$ McCubbins and Schwarz, Loc.Cit.

${ }^{8}$ Ignas Kleden, Menulis Politik: Indonesia sebagai Utopia (Political Writing: Indonesia as Utopia), Jakarta: Penerbit Buku Kompas, (2001), p. 157.

${ }^{9}$ Ibid., p. 158.

${ }^{10}$ As stated by Ridlwan and Nurbaningsih, even if the parliament opposition raises have not yet to be adopted within the Indonesian governance system, at least a revision of the law aimed at guaranteeing the members of parliament (MPs) to perform their role freely according to conscience. See: Zulkarnain Ridlwan and Enny Nurbaningsih, (2018), "Law Revision on Indonesian Parliament's Oversight Function: Facing the Challenges of Democracy" in The 1st
} 
How is the condition of institutionalisation on current DPR oversight function and its relation to the strengthening public recognition upon Indonesian presidential's representativeness? Recognition here means acknowledgement that something was authorised to be done ${ }^{11}$ or confirmation that an act done by another person was authorised ${ }^{12}$. Public recognition upon the presidential system, in this case, means people's acknowledgement that the system is worthy and fit for public concerns.

In that framework, the presidential system recognition by the public ought to be strengthened by the presence of parliamentary oversight. Certainly, in this case, effective parliamentary oversight is required, leading to an active-constructive frame of oversight. It is not parliamentary oversight that is carried out in negative-destructive terms. Nor is it apatheticcompromising. Because the last two mentioned conditions will weaken the people's recognition upon the presidential system. Weak, in this case, means a president who does not get recognition from the people.

Both of those conditions, caused by the arbitrary presidency due to negative collaboration with the parliament, creates a state of compromise governance without the presence of a legislative body that carries out oversight. Or even because the ineffective presidential leadership due to destructive parliamentary oversight, will always be different from the president's step, which tends to be negative.

Institutionally, DPR Committees are the main actors of oversight. Within it, DPR's oversight activity upon government institutions conducted and should be well organised. However, based on many surveys of its performance, the DPR committees are considered not working well according to public expectation. Availability of committees that only amount to 11 compared to its 113 work partners suspected to be one of the causes.

17/2014 Law submit the authority to form a committee to the DPR itself. Amount and distribution of its partners can be adjusted according to needs. So whenever the DPR feels the need, the number of committees can be expanded. The question is, how many DPR committees are needed to carry out the oversight function over the extent of the work area of government agencies? What is the minimum number of DPR committees that must be regulated in the amendment to Law 17/2014 so that supervision can be held more effectively?

Regulatory tracking methods are chosen by making comparisons. To find best practices in the relationship between parliamentary oversight and

International Conference on South East Asia Studies, KnE Social Sciences, (2016), pp.573593.

${ }^{11}$ Susan Ellis Wild (Legal Ed.), Webster's New World Law Dictionary, NJ: Wiley Publishing, (2006), p. 217.

${ }^{12}$ Bryan A. Garner (Ed.), Black's Law Dictionary, St.Paul: West Group, (1999), p. 1277. 
governmental execution by the government is pursued by making comparisons. Comparison method means learning from the experiences of other parties. ${ }^{13}$ The comparison provides a foundation to make a statement about the real data with regularly and to evaluate and interpret certain conditions substantive and theoretical. ${ }^{14}$ The comparison does a central role in the formation of the concept with a focus on the similarities and differences between cases. Comparisons are routinely used to test hypotheses and contribute inductive discovery of new hypotheses and to construct a theory. ${ }^{15}$

The most common comparison of the legislature (parliament) focuses on the strength or weakness on the part of the institution. ${ }^{16}$ This paper takes the US and UK as comparisons. From the US as the pioneer country of the presidential system, examples will be taken of how the US House of Representatives' oversight of government can be effective. Similarly, from the UK -especially British House of Commons- as the first country to run a model of parliamentary government will be adopted practices as well as instruments that can be adopted for the presidential government without changing the principles prevailing in the presidential system. This search focuses on developing institutional oversight functions, so the number of committees is one of the main focuses to be discussed.

\section{B. Discussion}

\section{Indonesian Presidential System}

Broadly, the governance system adopted by the countries include the two systems, the parliamentary system and the presidential system. But in its development, there are also countries that adopted the combination of the two systems (quasi system). ${ }^{17}$ This classification saw from the nature of the relationship between bodies or organs that hold the state power. The parliamentary system is a system of government that most widely applied

${ }^{13}$ Giovanni Sartori, "Comparing and Miscomparing", Journal of Theoretical Politics, 3 (3), (1991), p. 245.

${ }^{14}$ Charles C. Ragin. The Comparative Method: Moving Beyond Qualitative and Quantitative Strategies, Berkeley: University of California Press Limited, (1987), p. 1.

${ }^{15}$ David Collier, "The Comparative Method", in A. Finiftner (ed.), Political Science: The State of Discipline, Washington, D.C.: APSA, (1993), p. 105.

16 Taiabur Rahman. Parliamentary Control and Government Accountability in South Asia: A comparative analysis of Bangladesh, India and Sri Lanka, Routledge Advances in South Asian Study. New York: Routledge, (2007), p. 31.

${ }^{17}$ José Antonio Cheibub and Fernando Limongi, "Legislative-Executive Relations", in Tom Ginsburg and Rosalind Dixon (Ed.). Comparative Constitutional Law, Cheltenham: Edward Elgar Publishing Limited, (2011), p. 212. 
throughout the world, of all variants of the system of government. ${ }^{18}$ In a simple distinction, the parliamentary and presidential system could be seen in the portrait of the relationship between the government and the parliament. If there is interdependence between the two, that is parliamentary, while the presidential interpreted if the government and parliament of each standalone. ${ }^{19}$

Soemantri, in line with Asshiddiqie, suggests a three-division system of government; parliamentary, presidential, and mixed government. ${ }^{20}$ According to Kusuma's study, Indonesian's government system different from the US presidential system, also different from the parliamentary system as in England, Indonesia's system similar to Republic V of France. ${ }^{21}$ The executivelegislative relationship can be seen in its mutual attraction, in a parliamentary system the executive can be imposed by parliament with a no-confidence vote. As control of that parliament actions, the executive may propose to the head of state to dissolve parliament. In the presidential system, the incumbent president cannot be imposed by parliament under normal circumstances. Nevertheless, a mechanism presidential impeachment available in abnormal conditions, with the reason of law violations, for instance.

The so-called presidential system also can be identified when the executive not accountable to parliament. In a presidential system, cabinet not responsible collectively, but each minister individually responsible to the president. The presidential system also does not recognise the ultimate supremacy institution. As the core characteristic of the presidential system, the representative body does not have the ultimate supremacy upon the state.

Indonesia has the experience changed between the presidential system of government and parliamentary. Based on several base criteria above, the current adopted system in Indonesia is presidential. The presidential system more precisely executed in Indonesia for some reason, the strongest one lead by Indonesia's experienced government instability as happened in the 1950s and 2001. The presidential system has the presidential term to guarantee more stability because the government does not depend on the parliament.

${ }^{18}$ Douglas V. Verney, "Parliamentary Government and Presidential Government", in Arend Lijphart, Parliamentary Versus Presidential Government. Oxford: Oxford University Press, (1992), p. 31.

${ }^{19}$ Alfred Stepan \& Cindy Skach, "Constitutional Frameworks and Democratic Consolidation", World Politics, 46 (1), (1993), pp. 1-22.

${ }^{20}$ Sri Soemantri, Pengantar Perbandingan Antar Hukum Tata Negara (Introduction to Comparative Constitutional Law). Jakarta: CV. Rajawali, (1981), pp. 76-80; in line with Jimly Asshiddiqie. Pokok-Pokok Hukum Tata Negara Indonesia Pasca Reformasi (Principles of Constitutional Law at the Indonesia Post-Reformation), Jakarta: Buana Ilmu Populer, (2007), p. 311.

21 R.M. Ananda B. Kusuma, "Sistem Pemerintahan Indonesia (Indonesian Government System)", Jurnal Konstitusi, 1 (1), (2004). p. 150. 


\section{DPR Oversight Function and Its Affecting Factors}

The existence of the parliament in the process of policy formation is very important ${ }^{22}$, especially in the role oppose or change the policy initiatives that come from the government ${ }^{23}$. A strong parliament makes decisions and takes action independently from the government in a parliamentary system. Access to information and expertise in policy from sources that are not associated with the government, which is usually in stable condition and the special committee of parliament, is generally regarded as the conditions necessary for a strong parliament any regime rule. ${ }^{24}$

Parliamentary oversight defined as a review, monitoring and oversight of the government and the institutions of public, also includes the implementation of legislation and policies. Yamamoto stated the main functions of the parliamentary oversight could be described as follows: ${ }^{25} 1$ ) to detect and prevent abuse, arbitrary behaviour, or illegal and unconstitutional behaviour from the government and public institutions; 2) to maintain the government's account of how the taxpayers' money is used; 3) to ensure that the measures announced by the government and approved by parliament actually delivered; and 4) to improve the transparency of government enforcement and improving public confidence in the government, because this is a condition of effective policy.

Based on the reference, one of several factors that affect the function of parliamentary oversight influenced by the composition of institutional factors, tools, and dependence. ${ }^{26}$ Committees and subcommittees have been an effective oversight tool in a presidential system and a parliamentary system. It could be traced from the various retention of the US Congress and the British Parliament. By the committees and subcommittees, the oversight function conducted without abandon another legislative function. As asserted by Petersen, select committees (in British Parliament and the U.S. House)

\footnotetext{
${ }^{22}$ M. Mezey. Comparative Legislatures, Durham: Duke University Press, (1979), pp. 23.

${ }^{23}$ N.W. Polsby. "Legislatures", in F.I. Greenstein and N.W. Polsby (Eds.), Handbook of Political Science, Vol. 5. (Reading: Addition-Wesley, 1975), p. 277; M. Mezey. Comparative... Op.Cit, p. 26-27.

${ }^{24}$ J.M. Carey. "Parties, Coalitions and the Chilean Congress in the 1990s", in M. Scott and B. Nacif (Eds.), Legislative Politics in Latin America, New York: Cambridge University Press, (2002), p. 153; Philip Norton, "The Legislative Powers of Parliaments", in C. Flinterman, A.W. Herings and L. Waddington (Eds.). The Evolving Role of Parliaments in Europe. Antwerpen: Maklu Uitgevers, (1994), pp. 15-35; Kaare Strøm, "Parliamentary Committees in European Democracies", Journal of Legislative Studies, 4 (1), (1998), pp. 20-59.

${ }_{25}$ Hironori Yamamoto, Tools for Parliamentary Oversight: A Comparative Study of 88 National Parliaments, Switzerland: Inter-Parliament Union, (2007), pp. 9-10.

${ }^{26}$ B. Rockman. 'Legislative-Executive Relations and Legislative Oversight', in Loewenburg, G., Patterson, S. \& Jewell, M. (Eds.) Handbook of Legislative Research. Cambridge, MA, Harvard University Press, (1985), pp. 519-572.
} 
review executive department operations (there is generally one select committee for each department). ${ }^{27}$ In DPR, the availability of committees is not equal to the number of government departments, as explained in the table below:

Table 1. Distribution of DPR Committees Working Area ${ }^{28}$

\begin{tabular}{|c|c|c|}
\hline $\begin{array}{c}\text { Distribution } \\
\text { of DPR } \\
\text { Committees }\end{array}$ & Committee Partners & \begin{tabular}{|l|} 
Numbe \\
$\mathbf{r} \quad$ of \\
Partner \\
s \\
\end{tabular} \\
\hline $\begin{array}{l}\text { Committee I: } \\
\text { Committee } \\
\text { for Defense, } \\
\text { Foreign } \\
\text { Affairs and } \\
\text { Information }\end{array}$ & $\begin{array}{l}\text { Ministry of Defense, Ministry of Foreign } \\
\text { Affairs, Ministry of Communication and } \\
\text { Information, TNI Commander, TNI } \\
\text { Headquarters (Army, Navy and Air } \\
\text { Force), National Defense Council, } \\
\text { National Defense Institution, State } \\
\text { Intelligence Agency, State Password } \\
\text { Institution, LKBN Antara Public } \\
\text { Company, Central Information } \\
\text { Committee, Indonesian Broadcasting } \\
\text { Committee, TVRI (Television), Radio } \\
\text { (RRI), Press Council, Film Censorship } \\
\text { Institute. }\end{array}$ & 18 \\
\hline $\begin{array}{l}\text { Committee } \\
\text { II: Domestic } \\
\text { Committee, } \\
\text { State } \\
\text { Secretariat } \\
\text { and Election }\end{array}$ & $\begin{array}{l}\text { Ministry of Home Affairs, Ministry of } \\
\text { State Secretariat, Ministry of Agrarian and } \\
\text { Spatial Planning of the National Land } \\
\text { Agency, Cabinet Secretariat, } \\
\text { Ombudsman, General Election } \\
\text { Committee, Election Supervisory } \\
\text { Agency, Ministry of Administrative } \\
\text { Reform- Bureaucratic Reform, State Civil } \\
\text { Service Agency, State Administration } \\
\text { Agency, National Archives of the } \\
\text { Republic of Indonesia. }\end{array}$ & 12 \\
\hline
\end{tabular}

${ }^{27}$ R. Eric Petersen. "Parliament and Congress: A Brief Comparison of the British House of Commons and the U.S. House of Representatives", Congressional Research Service, Updated May 19, 2005.

${ }^{28}$ http://dpr.go.id/akd/komisi. 


\begin{tabular}{|c|c|c|}
\hline $\begin{array}{l}\text { Committee } \\
\text { III: Law, } \\
\text { Human } \\
\text { Rights and } \\
\text { Security }\end{array}$ & $\begin{array}{l}\text { Ministry of Law and Human Rights, } \\
\text { Attorney General's Office, National } \\
\text { Police, Corruption Eradication } \\
\text { Committee, National Human Rights } \\
\text { Committee, National Law Committee, } \\
\text { Secretary General of the Supreme Court, } \\
\text { Secretary General of the Constitutional } \\
\text { Court, Secretary General of the House, } \\
\text { Secretary General of the People's } \\
\text { Consultative Assembly, Secretary } \\
\text { General of the Regional Representatives } \\
\text { Council, Financial Transaction Reports } \\
\text { and Analysis Center, Institutions } \\
\text { Protection of Witnesses and Victims, } \\
\text { National Narcotics Agency, National } \\
\text { Agency for Combating Terrorism. }\end{array}$ & 15 \\
\hline $\begin{array}{l}\text { Committee } \\
\text { IV: } \\
\text { Environment, } \\
\text { Agriculture, } \\
\text { Food and } \\
\text { Maritime } \\
\text { Committee }\end{array}$ & $\begin{array}{l}\text { Ministry of Agriculture, Ministry of } \\
\text { Environment and Forestry, Ministry of } \\
\text { Maritime Affairs and Fisheries, Logistics } \\
\text { Affairs Agency, National Maritime } \\
\text { Council }\end{array}$ & 5 \\
\hline $\begin{array}{l}\text { Committee } \\
\mathrm{V} \text { : } \\
\text { Infrastructure } \\
\text { and } \\
\text { Transportatio } \\
\mathrm{n}\end{array}$ & $\begin{array}{l}\text { Ministry of Public Works and Housing, } \\
\text { Ministry of Transportation, Meteorology, } \\
\text { Climatology and Geophysics Agency, } \\
\text { National Search and Relief Agency, } \\
\text { Sidoarjo Mud Prevention Agency, } \\
\text { Surabaya Madura Development Agency, } \\
\text { Ministry of Village, Development of } \\
\text { Disadvantaged Regions and } \\
\text { Transmigration }\end{array}$ & 7 \\
\hline $\begin{array}{l}\text { Committee } \\
\text { VI: Industry, } \\
\text { Investment } \\
\text { and Business } \\
\text { Competition }\end{array}$ & $\begin{array}{l}\text { Ministry of Industry, Ministry of Trade, } \\
\text { Ministry of Cooperatives and Micro, } \\
\text { Small and Medium Enterprises, Ministry } \\
\text { of State-Owned Enterprises, Investment } \\
\text { Coordinating Board, National } \\
\text { Standardization Agency, National }\end{array}$ & 11 \\
\hline
\end{tabular}




\begin{tabular}{|c|c|c|}
\hline & $\begin{array}{l}\text { Consumer Protection Agency, Business } \\
\text { Competition Supervisory Committee, } \\
\text { Batam Excess Free Trade Zone and Free } \\
\text { Port Agency, Sabang, Indonesian } \\
\text { Cooperative Council }\end{array}$ & \\
\hline $\begin{array}{l}\text { Committee } \\
\text { VII: Energy } \\
\text { and Research } \\
\text { and } \\
\text { Technology } \\
\text { Committee }\end{array}$ & $\begin{array}{l}\text { The Ministry of Energy and Mineral } \\
\text { Resources, Ministry of Research, } \\
\text { Technology and Higher Education, } \\
\text { Agency for the Assessment and } \\
\text { Application of Technology, Nuclear } \\
\text { Energy Agency, Nuclear Energy } \\
\text { Supervisory Agency, Geospatial } \\
\text { Coordination Agency, Regulatory } \\
\text { Agency for Downstream Oil and Gas, } \\
\text { Special Oil and Gas Work Unit, National } \\
\text { Aeronautics and Space Agency, Institute } \\
\text { of Sciences Indonesian Knowledge, } \\
\text { Eikjman Institute, National Research } \\
\text { Council, National Energy Council, } \\
\text { Science and Technology Demonstration } \\
\text { Center }\end{array}$ & 14 \\
\hline $\begin{array}{l}\text { Committee } \\
\text { VIII: } \\
\text { Religion and } \\
\text { Social } \\
\text { Affairs }\end{array}$ & $\begin{array}{l}\text { Ministry of Religion, Ministry of Social } \\
\text { Affairs, Ministry of Women's } \\
\text { Empowerment and Child Protection, } \\
\text { Indonesian Child Protection Committee, } \\
\text { National Disaster Management Agency, } \\
\text { National Zakat Agency, Indonesian Waqf } \\
\text { Agency }\end{array}$ & 7 \\
\hline $\begin{array}{l}\text { Committee } \\
\text { IX: Health } \\
\text { and } \\
\text { Employment }\end{array}$ & $\begin{array}{l}\text { Ministry of Health, Ministry of } \\
\text { Manpower, National Population and } \\
\text { Family Planning Agency, Food and Drug } \\
\text { Supervisory Agency, National Agency for } \\
\text { Placement and Protection of Workers, } \\
\text { Health Social Security Organizing } \\
\text { Agency, Health Social Security } \\
\text { Organizing Agency - Employment }\end{array}$ & 7 \\
\hline
\end{tabular}




\begin{tabular}{|l|l|l|}
\hline $\begin{array}{l}\text { Committee } \\
\text { X: } \\
\begin{array}{l}\text { Education, } \\
\text { Sports, and } \\
\text { History }\end{array}\end{array}$ & $\begin{array}{l}\text { Ministry of Education and Culture, } \\
\text { Ministry of Tourism, Ministry of Youth } \\
\text { and Sports, National Library }\end{array}$ & 4 \\
\hline $\begin{array}{l}\text { Committee } \\
\text { XI: Finance } \\
\text { and Banking }\end{array}$ & $\begin{array}{l}\text { Ministry of Finance, National } \\
\text { Development Planning Agency, Financial } \\
\text { and Development Supervisory Agency, }\end{array}$ & 13 \\
& $\begin{array}{l}\text { Central Statistics Agency, Secretary } \\
\text { General of the Audit Board, Bank }\end{array}$ & \\
& $\begin{array}{l}\text { Indonesia, Banks, Non-Bank Financial } \\
\text { Institutions, Indonesian Export Financing }\end{array}$ & \\
& $\begin{array}{l}\text { Institutions, Government Goods and } \\
\text { Services Procurement Institutions, } \\
\text { Deposit Insurance Corporation, Financial }\end{array}$ & \\
Services Authority. & \\
\hline
\end{tabular}

Table 1 shows that the work of 11 DPR committees is not evenly distributed, and it even clear that there is an imbalance of oversight workloads. For example, Committee X, which only has four government institutions as the scope of oversight, while Committee I has 18 . Such quantity also explains that the oversight work of each committee will differ in quality. Committees that have little work area are more likely to present quality oversight because of fewer focus points. That work scope condition also makes routine oversight is the most dominant function carried out by DPR Members. Besides, the DPR members should not only focus more on the supervisory function, because there are legislative functions and budget functions that require the same portion of attention.

\section{The institutionalisation of Committee and Subcommittee}

A survey of 80 s state legislature mentions that the effectiveness of parliamentary oversight tools varies according to the shape of the country. ${ }^{29}$ In the presidential country, the most important tool are the committee, plenary hearings, and the ombudsman; in the semi-presidential country, the most important tool is the session of questions, interpellation, and ombudsman, and

${ }^{29}$ Hironori Yamamoto. Loc.Cit.; Riccardo Pelizzo and Stapenhurst, R. 2004. "Tools for Legislative Oversight: an Empirical Investigation", Quaderni di Scienza Politica/ Notebook of Political Science, 11 (1). 
in the parliamentary country the most important tools are interpellation. ${ }^{30}$ Norton asserts that the Parliament with strong institutionalisation has a greater ability to force the government than the weak parliament in its institutionalisation. ${ }^{31}$ The core of institutionalisation is specialisation through committees.

There is no way to consider the best instrument to balance the executive relationship with parliament. But it has been widely known that a way to strengthen the parliament while still keeping the executive from weakening, by maximising the function of committees. ${ }^{32}$ The Committee gave parliament to (simultaneously) perform many functions that may -without it- cannot be implemented. ${ }^{33}$ For example, parliamentary committees help reduce the workload and carry out different functions more efficiently. Committees also guided the legislation and provide the essential tools in the framework of government oversight. Committees can also offer MPs a variety of advantages and opportunities as increase their capacity in specialisation in the realm of policy, ${ }^{34}$ providing tools for them to continue to be busy and feel useful, ${ }^{35}$ and make sure they become more active and profitable participation in the governance process. ${ }^{36}$ The main thing has been understood; the committee became one of the most effective tools to bolster the authority of parliament to deal with the executive. ${ }^{37}$

Countries with a well-established system of government would have a parliamentary institutional design that has stabilised, including in terms of the existence of the committees and subcommittees in it. Which Indonesia can take lessons either in the institutionalisation of committees and subcommittees in the parliament? The two different models with different government systems might be the references. The examples of institutional design from

\footnotetext{
${ }^{30}$ Frederick Stapenhurst, et.al. Loc.Cit.

${ }^{31}$ Norton Philip, "Conclusion: Do Parliaments Make a Difference", in Philip Norton (Ed.), Parliaments and Governments in Western Europe, London: Frank Cass, (1998), p. 196.

${ }^{32}$ Anthony King. 'How To Strengthen Legislatures-Assuming That We Want To' in Norman Ornstein (ed), The Role of the Legislature in Western Democracies, Washington: American Enterprise Institute for Public Policy Research, (1981), pp. 77-89; Nizam Ahmed. (2010). "Parliamentary Committees and Parliamentary Government in Bangladesh", Contemporary South Asia, 10 (1), pp. 11-36.

${ }^{33}$ Susan Benda. "Committees In Legislatures: A Division of Labour" in Lawrence Longley and Attila Agh (Eds.). The Changing Roles of Parliamentary Committees. Appleton: Research Committee of Legislative Specialists, International Political Science Association, (1997), p. 17.

${ }^{34}$ Hugh Emy, The Politics of Australian Democracy. Melbourne: Macmillan, (1978), p. 406.

${ }^{35}$ Michael Rush, "Parliamentary committees and parliamentary government: the British and Canadian experiences", The Journal of Commonwealth and Comparative Politics, 20 (2), (1982), p. 151.

${ }^{36}$ Michael Jogerst, Reform in the British House of Commons, Lexington: The University of Kentucky Press, (1993), p. 26.

${ }^{37}$ Rod Hague \& Martin Harrop. Comparative Government. London: Macmillan, (1982), p. 157.
} 
the two countries are expected to represent better the critical supervision of the Indonesian people who represent the ideals of democracy in Indonesia. ${ }^{38}$ US model (Presidential) and British model (Parliamentary) in exercising congressional/ parliamentary oversight through committees and subcommittees.

\section{a. First, US Model.}

The US Constitution generally acknowledged as a strong expression of the doctrine of separation power. Separation of power, a doctrine that establishes the formation of separate branches of government, with clear and limited powers. In that system, complete independence of executive, legislative and judicial functions is formed while maintaining the overlapping forces between them to ensure that they examine and balance each other. ${ }^{39}$ The drafters of the US Constitution distribute power among three branches of the federal government: legislative, executive and judicial.

Those federal government bound by higher constitutional law, which guides and limits the use of power to protect people's freedoms and avoid tyranny. ${ }^{40}$ Congress is the identity of the Senate and the House, even though most of their work is independent. Members of Congress bring local concerns to the national debate, and they work to ensure that the specific needs and concerns of their constituents are dressed in the national legislature. ${ }^{41}$

Congress does an important role in the functioning of the executive branch. Its responsibilities range from counting electoral votes, providing funds for the executive branch, and monitoring the implementation of laws. The Senate has the power to confirm executive appointments. Both the House and Senate can launch investigations into executive activities, and both chambers work together to seek the impeachment and conviction of top officials accused of wrongdoing. ${ }^{42}$ Congress has delegated to the executive branch broad authority over agencies and programs it has created. Its oversight power helps ensure that the executive branch performs as Congress intends.

Hearings and investigations, the most publicised form of oversight, provide some of the most colourful moments on Capitol Hill, as seen in the

\footnotetext{
${ }^{38}$ Zulkarnain Ridlwan. "Cita Demokrasi Indonesia dalam Politik Hukum Pengawasan Dewan Perwakilan Rakyat Terhadap Pemerintah" [Indonesian democratic ideals in the legal politics supervision of the house of representatives of the government]. Jurnal Konstitusi, 12 (2), (2015), pp.305-327.

${ }^{39}$ Craig Calhoun, (Ed.). Dictionary of the Social Science, New York: Oxford University Press, (2002), p. 435.

40 John J. Patrick, et.al, The Oxford guide to the United States government, New York: Oxford University Press, (2001), pp. 585-586.

${ }^{41}$ Ibid., p. 140.

${ }^{42}$ David R. Tarr \& Ann O'Connor (Eds.) Congress A to Z, Fourth Edition, Washington DC: CQ Press, (2003), p. 156.
} 
water-gate scandal, Iran-contra affair, and the impeachment of President Bill Clinton. Members of Congress have been known to use the subpoena power of a committee to compel executive branch officials to testify or to produce documents. Lawmakers also exercise their oversight function through informal contacts with executive officials, as well as statements made in committees and conference reports also during hearings and floor debate. Staffs of individual members of Congress conduct ongoing oversight through casework - the handling of constituent questions and problems regarding agency actions. ${ }^{43}$

US Congress developed an oversight committee which established or assigned the duty of overseeing the administration of the laws. Congress vested the "watchdog" responsibility in the standing committees, each responsible within its Jurisdiction for overseeing the execution of laws. ${ }^{44}$ Besides being known, there are investigative committees, legislative committees that carry out fact-finding roles as assistance for the law-making process. The investigative committee can force witnesses to attend and produce relevant material. Investigations carried out by special committees made for that purpose.

Increasingly, Congress has relied on investigations as a means of seeking to regain its position of power vis-a-vis the executive branch, which has steadily gained in relative power during this Century. ${ }^{45}$ Committees conduct investigations that highlight national problems or disclose official wrongdoing. They are also responsible for congressional oversight of government programs and agencies. By the 104th Congress (1995-1997), most committees could have no more than five subcommittees and most member no more than four subcommittee assignments. At the beginning of the 106th Congress (1999-2001), the House changes its rules to allow committees to add the sixth subcommittee if one of its subcommittees dealt with oversight. In the 108th Congress, subcommittees in the House and Senate total amount to 165 unit. $^{46}$ The division of work of the committee in the House as follows: ${ }^{47}$

1) Agriculture

2) Allocation

3) Armed Services

${ }^{43}$ Ibid., p. 329.

${ }^{44}$ Jack C. Plano \& Milton Greenberg, The American Political Dictionary, Eleventh Edition, Belmont: Wadsworth/Thomson Learning, (2002), p. 192.

45 Ibid., p. 168.

${ }^{46}$ Tarr and O'Connor, Op.Cit., pp. 90-92.

${ }^{47}$ See: https://www.congress.gov/committees, Accessed Februari 2019. See also: Rule X Organization of Committees" in Karen L. Hass (Prepared by.) Rules of the House of Representatives - 114th Congress, Clerk of the House of Representatives, January 6, (2015), pp. 6-9. 
4) Budget

5) Education and Labor

6) Energy and Trade

7) Ethics

8) Financial Services

9) Foreign Affairs

10) Homeland Security

11) Housing

12) Court

13) Natural Resources

14) Government Oversight and Reform

15) Rules

16) Science, Space and Technology

17) Small Trade

18) Transportation and Infrastructure

19) Veteran Affairs

20) State Finance

The division of members in most of the US Congress are divided on work across a wide range of committees and sub-committees. ${ }^{48}$ The cornerstone of a wide discussion on institutional theory, it can be hypothesised that the rules/ standard operating procedures, as well as the history of the stability and sustainability of the institution, is vital for the performance of the institution. The performance of agencies is the role of parliamentary committees in ensuring government accountability. ${ }^{49}$ Jeff Stier wrote in Forbes page, highlighting the importance of the oversight of the US Congress as a key element of checks and balances that prevent the accumulation of power also an abuse of power in all parts of government. ${ }^{50}$

According to Madjid, Indonesia, since the beginning has been taking the US as an example of the implementation of the presidential system. ${ }^{51}$ With the example of the US, the nation founders also designed the implementation of democracy with the periodic presidential government. They also adhere to the principles of civil liberties, namely freedom of expression, assembly, and association. Overall insights, it also has become a common spirit every Constitution that has ever had throughout Indonesia's history, such as Constitution of the Republic of United States of Indonesia (1949-1950) and

\footnotetext{
${ }^{48}$ Lewis A. Froman Jr, "Organization Theory and the Explanation of Important Characteristics of Congress", The American Political Science Review, 62 (2), (1968), pp. 523.

${ }^{49}$ Taiabur Rahman, Op.Cit., p. 22.

${ }^{50}$ Jeff Stier, "Checks and Balances ari Critical to Public Health", Opinion on Forbes, 28 Juli 2016, Washington DC: National Center for Public Policy Research.

${ }^{51}$ Nurcholish Madjid, Indonesia Kita, (Our Indonesia), Jakarta: Gramedia, (2004), pp. 88-89.
} 
the Provisional Constitution of Indonesia (1950-1959), and 1945 Constitution after amendments (1999-2002) itself, which is now in effect.

State practice in the United States in the relationship between the executive and the legislature as called by Richard E. Neustadt as the "separated institutions sharing powers". ${ }^{52}$ So that, although separate, Congress and the president need each other. However, dissent or bitter rhetoric, they will immediately look for a variety of compromises so that the system can run. Congress also has the important responsibility of oversight of executive branch activities to ensure that its legislative intent is being carried out and to remedy the condition. ${ }^{53}$ The separation of powers that characterises the American political system imposes real accountability on the Executive. While in parliamentary democracies often have a looser concept of accountability with less separate powers than concentrated, especially between the Legislative and Executive Bodies. ${ }^{54}$

\section{b. Second, British Model.}

Based on the parliamentary system, the British Parliament put a special monitoring committee in each parliamentary committee to function properly. Departmental select committees, established in 1979 and comprising backbench MPs from all the parliamentary parties, scrutinise each government department's policies, activities and spending. There are currently nineteen committees, each shadowing the work of a major government department. They generally conduct inquiries on specific departmental issues and publish reports, to which the government must respond. Often colloquially called 'watchdog' committees, they have been called the single most important weapon of increased parliamentary influence in the twentieth century. ${ }^{55}$ The division of work of the committee in the House of Commons as follows: ${ }^{56}$

1) Business, Business Organizations and Regulatory Reform

2) Children, Schools and Families

3) Local Community and Government

4) Culture, Media and Sports

5) Defence

6) Environment, Food and Village Affairs

7) Environmental Audit

52 Richard E. Neustadt, Presidential Power and the Modern Presidents: The Politics of Leadership from Roosevelt to Reagan, New York: Free Press, (1990), as cited by Michael Nelson (Ed.), The Presidency A to Z, Washington: CQ Press, (2003), p. 100.

${ }^{53}$ Ibid., p. 106.

${ }^{54}$ Harshan Kumarasingham, "Exporting Executive Accountability? Westminster Legacies of Executive Power", Parliamentary Affairs, 66, (2013), p. 580.

${ }_{55}$ Moyra Grant, The UK Parliament, Edinburgh: Edinburgh University Press, (2009), p. 126.

${ }^{56}$ See: www.parliament.uk/about/how/committees/, accessed on Februari 2019. 
8) Foreign Affairs

9) Health

10) Domestic Affairs

11) Innovation, Higher Education, and Skills

12) International Development

13) Justice

14) Northern Ireland Affairs

15) Scottish Affairs

16) Transportation

17) Treasury

18) Wales Affairs

19) Employment and Retirement

As stated by Benton and Russel, although standing committees can be influential in key policy areas, they also play a role in drawing attention to specific or neglected issues that may not get the minister's attention adequately. ${ }^{57}$ The committee can encourage certain issues to become the ministry's agenda. The committee can also be a bridge of communication between government ministries. For this reason, Committee investigations are used to ensure that ministries weigh their policy options better. Even in some cases, the committee offers stronger openness than the media, or outside groups because the government has to respond to their recommendations formally.

The ability of special committees in the British Parliament to expose poor policymaking in the public arena is carried out by calling witnesses. This condition motivated officials, and ministers, to ensure that their policies were watertight. ${ }^{58}$ Compliance with the committee due to its deep research on policy. Blondel described it as a preventative measure, so ministers had to ask themselves how elected committees in parliament tend to react. ${ }^{59}$ So, it has been agreed that committee consultations are very important, as also stated by Power and Khmelko. ${ }^{60}$

\section{Conclusion}

Comparative results from the US model were taken, the Executive's respect to the call of the House's Select Committees in the process of oversight

57 Meghan Benton \& Meg Russell, "Assessing the Impact of Parliamentary Oversight Committees: The Select Committees in the British House of Commons", Journal of Parliamentary Affairs, 66, (2013), pp. 772-797.

${ }^{58}$ Ibid., p. 790-791.

${ }^{59}$ Ibid., p. 792.

${ }^{60}$ See: Greg Power. Global Parliamentary Report; The changing nature of parliamentary representative, Denmark: UNDP and IPU, (2012), pp. 32-33; I. S. Khmelko, et.al. (2010). "Committees and Legislative Strengthening: The Growing Influence of Committees in Ukraine's Legislative Process". The Journal of Legislative Studies, 1 (16), (2010), pp. 73-95. 
of the government significantly influence the oversight result. From the British model, parliamentary oversight exercised in sub-committees, by that oversight can be focused, and through a simpler administrative process. Oversight can be done more effectively because parliamentarians have focused on the special work of oversight within the sub-committee.

DPR can follow the pattern of oversight by shrinking its workspace into sub-committees in each committee. Then in each DPR committee, there will be a special sub-committee to supervise. This way, also, will make localisation and isolation in the sub-committee of oversight, also can divide the focus of the DPR work, which also has the function of budget and the function of legislation. Evaluation of DPR's legislation function in the last two periods of DPR complained about its poor performance. Whereas as stated by many experts, the construction of the constitution of Indonesia after the amendment of the 1945 Constitution (1999-2002) emphasized the DPR on its legislative function rather than the function of budget and supervisory function because the oversight function was assisted by the presence of Regional Representative Council and Constitutional Court as a new state institution.

Therefore, to strengthen public recognition on the presidential system through the DPR's oversight function, need to be regulated in the MD3 Act, specifically in the amendment to 17/2014 Act of specialisation on the committee work area. The division of labour in only 11 DPR committees cannot balance the ministry's work area. The many working areas of the ministry, which are divided into 34 departments, make the DPR's oversight work ineffective. Moreover, the supervisory working area of the DPR committee also includes other government agencies besides the ministry.

The division of existing working partners is not ideal to be able to present an effective institutional oversight function of the DPR. Inequality of workload between one committee and another makes oversight not optically worked. For this reason, revisions to 17/2014 Law should set a maximum limit of five working partners for each DPR committee. Then the total number of committees adjusts the distribution of workload. Thus, the division of labour supervision becomes more evenly distributed. With a narrower oversight working area, MPs could also perform in the legislation and budget function. With the main role of the DPR, the Indonesian presidential will be more representative in the public view.

\section{A. Book}

\section{Bibliography}

Asshiddiqie, J. (2007). Pokok-Pokok Hukum Tata Negara Indonesia Pasca Reformasi (Principles of Constitutional Law at the Indonesia PostReformation). Jakarta: Buana Ilmu Populer. 
Calhoun, C. (Ed.). (2002). Dictionary of Social Science. New York: Oxford University Press.

Cheibub, J.A. and Limongi, F. (2011)."Legislative-Executive Relations”, in Tom Ginsburg and Rosalind Dixon (Ed.). Comparative Constitutional Law. Cheltenham: Edward Elgar Publishing Limited.

Garner, B.A. (Ed.). (1999). Black's Law Dictionary. St.Paul: West Group.

Grant, M. (2009). The UK Parliament. Edinburgh: Edinburgh University Press.

Jogerst, M. (1993). Reform in the British House of Commons. Lexington: The University of Kentucky Press.

Mezey, M. (1979). Comparative Legislatures. Durham: Duke University Press.

Nelson, M. (2003). The Presidency A to Z. Washington DC: CQ Press

Neustadt, R.E. (1990). Presidential Power and the Modern Presidents: The Politics of Leadership from Roosevelt to Reagan. New York: Free Press.

Norton, P. and Ahmed, N. (1999). "Legislatures in Asia: Exploring Diversity." in Philip Norton and Nizam Ahmed (Eds.), Legislatures in Developmental Perspective. London: Frank Cass.

Olson, D.M. (2008). "Legislatures and Administration in Oversight and Budgets: Constraints, Means and Executives." in Rick Stapenhurst, Riccardo Pelizzo, David M. Olson, and Lisa von Trapp (Eds), Legislative Oversight and Budgeting: A World Perspective, Washington, D.C.: World Bank.

Patrick, J.J., Pious, R.M., and Ritchie, D.A. (2001). The Oxford guide to the United States government. New York: Oxford University Press.

Plano, J.C. and Greenberg, M. (2002). The American Political Dictionary, Eleventh Edition. Belmont: Wadsworth/Thomson Learning.

Power, G. (2012). Global Parliamentary Report; The changing nature of parliamentary representative. Denmark: UNDP and IPU.

Ragin, C.C. (1987). The Comparative Method: Moving Beyond Qualitative and Quantitative Strategies. Berkeley: University of California Press Limited.

Rahman, T. (2007). Parliamentary Control and Government Accountability in South Asia: A comparative analysis of Bangladesh, India and Sri Lanka, Routledge Advances in South Asian Study. New York: Routledge.

Rockman, B. (1985). 'Legislative-Executive Relations and Legislative Oversight', in Loewenburg, G., Patterson, S. and Jewell, M. (Eds.) Handbook of Legislative Research. Cambridge, MA, Harvard: University Press. 
Soemantri, S. (1981). Pengantar Perbandingan Antar Hukum Tata Negara (Introduction to Comparative Constitutional Law). Jakarta: CV. Rajawali.

Tarr, D.R., and O'Connor, A. (2003). Congress A to Z, Fourth Edition. Washington DC: CQ Press.

Verney, D. V. (1992). "Parliamentary Government and Presidential Government", in Arend Lijphart, Parliamentary Versus Presidential Government. Oxford: Oxford University Press.

Wild, S.E. (Legal Ed.). (2006). Webster's New World Law Dictionary. NJ: Wiley Publishing.

Yamamoto, H. (2007). Tools for Parliamentary Oversight: A Comparative Study of 88 National Parliaments. Switzerland: Inter-Parliament Union.

\section{B. Journal and Article}

Ahmed, N., "Parliamentary Committees and Parliamentary Government in Bangladesh", Contemporary South Asia, 10 (1), (2010).

Benda, S. "Committees In Legislatures: A Division of Labour" in Lawrence Longley and Attila Agh (Eds.). The Changing Roles of Parliamentary Committees. Appleton: Research Committee of Legislative Specialists, International Political Science Association, (1997).

Benton, M. and Russell, M. "Assessing the Impact of Parliamentary Oversight

Committees: The Select Committees in the British House of Commons", Journal of Parliamentary Affairs, 66, (2013).

Hass, K.L. (Prepared by). Rules of the House of Representatives - 114th Congress, (Clerk of the House of Representatives, January 6), (2015).

Khmelko, I. S., Wise, C. R. and Brown, T. L, "Committees and Legislative Strengthening: The Growing Influence of Committees in Ukraine's Legislative Process". The Journal of Legislative Studies, 1(16), (2010). Kumarasingham, H. "Exporting Executive Accountability? Westminster Legacies of Executive Power", Parliamentary Affairs. 66, (2013).

Kusuma, R.M.A.B. "Sistem Pemerintahan Indonesia (Indonesian Government System)", Jurnal Konstitusi, 1 (1), (2004).

Lederman, D, Loayza, N and Soares, R. "Accountability and Corruption: Political Institutions Do Matter", Economics and Politics, 17, (2005).

Pelizzo, R. and Stapenhurst, R. "Tools for Legislative Oversight: an Empirical Investigation”, Quaderni di Scienza Political Notebook of Political Science, 11 (1), (2004).

Persson, T., Roland, G. and Tabellini, G. "Separation of Powers and Political Accountability" Quarterly Journal of Economics Perspectives, 112 (11), (1997). 
Petersen, R. E. "Parliament and Congress: A Brief Comparison of the British House of Commons and the U.S. House of Representatives", Congressional Research Service, Updated May 19, (2005).

Ridlwan, Z. "Cita Demokrasi Indonesia dalam Politik Hukum Pengawasan Dewan Perwakilan Rakyat Terhadap Pemerintah", Jurnal Konstitusi, 12 (2), (2015).

Ridlwan, Z. and Nurbaningsih, E. "Law Revision on Indonesian Parliament's Oversight Function: Facing the Challenges of Democracy" in The 1st International Conference on South East Asia Studies, 2016, KnE Social Sciences, (2018).

Rush, M. "Parliamentary committees and parliamentary government: the British and Canadian experiences", The Journal of Commonwealth and Comparative Politics, 20 (2), (1982).

Stapenhurst, F., Jacobs, K and Pelizzo, R. "Corruption and Legislatures", Public Integrity, 16 (3), (2014).

Stepan, A. and Skach, C. "Constitutional Frameworks and Democratic Consolidation", World Politics, 46 (1), (1993).

Stier, J. "Checks and Balances are Critical to Public Health", Opinion on Forbes, Washington DC: National Center for Public Policy Research, (2016).

Strøm, K. "Parliamentary Committees in European Democracies", Journal of Legislative Studies, 4 (1), (1998).

Treisman, D. "The Causes of Corruption: A Cross-National Study" Journal of Public Economics, 76 (3), (2000).

\section{World Wide Web}

http://dpr.go.id/akd/komisi

https://www.congress.gov/committees

www.parliament.uk/about/how/committees/ 
